Original research article

\title{
Nutrition in pregnancy and pregnancy outcome in two primary health centres, Okpanam
}

\author{
Phoebe Nwamaka Kanikwu ${ }^{1}{ }^{*}$, Jessica Agada Jimmy ${ }^{2}$, Anthonia Chinwendu Emesowum ${ }^{3}$ \\ ${ }^{1}$ Edo University Iyamho, Department of Nursing Science, Iyamho, Edo State, Nigeria \\ ${ }^{2}$ Niger Delta University, Department of Maternal and Child Health Nursing, Wiberforce Island, Bayelsa State, Nigeria \\ ${ }^{3}$ Imo State University, Department of Nursing Science, Orlu Campus, Orlu, Imo State, Nigeria
}

\begin{abstract}
Background: Pregnancy is a nutritionally vulnerable period. The feto-maternal outcomes of pregnancies can be traced to the maternal antepartum nutritional status.

Objectives: The study assessed the knowledge of nutrition in pregnancy, nutritional practices in pregnancy and the outcome of the pregnancy for the mother and child among postpartum mothers.

Methods: A descriptive survey research of 54 postpartum mothers attending two Primary Health Centres in Okpanam, Delta State. Data collected with a self-developed questionnaire were analyzed using Statistical Package for Social Sciences (SPSS) version 22 and reported in the form of frequency, percentages and pie chart.

Results: $90.7 \%$ said pregnant women should eat for two, that is, for themselves and the unborn baby, and $35.2 \%$ consumed fewer soft drinks during pregnancy. The knowledge level of $50 \%$ and nutritional practice level of $42.9 \%$ indicated a low level of knowledge on nutrition in pregnancy as well as a low level of nutritional practice in pregnancy. Also, $66.7 \%$ of the postpartum mothers had good pregnancy outcome and about $50 \%$ of their babies had good pregnancy outcome.

Conclusions: Postpartum women had low nutritional knowledge level and low nutritional practice level in pregnancy. The majority had good maternal outcome but only about half of their babies had a good maternal outcome.
\end{abstract}

Keywords: Knowledge; Nutrition; Nutritional practice; Pregnancy; Pregnancy outcome

\section{Introduction}

Nutritional need varies across the human life cycle which includes pregnancy. Undoubtedly, healthy nutrition choices in pregnancy can help to promote fetal growth and development as well as boost the maternal immune system, promote the development of birthing structures/muscles, promote the overall health of the pregnant woman (Meija and Rezeberga, 2017), prepare the body for lactation (Nana and Zema, 2018) and improve feto-maternal outcomes (Kominiarek and Rajan, 2016). Adequate nutrition is highly recommended in pregnancy as an indispensable strategy to maintain healthy/recommended body weight during the period as well as to prevent the incidence of non-communicable diseases in the unborn child later in life (World Health Organization, 2018). Specifically, the first 1000 days of life which span from the conception to the second birthday is regarded as "the window of opportunity to prevent chronic malnutrition, childhood obesity and medical complications arising later in life" (United Nations Children's Fund, 2018). Hence, pregnancy is described as a nutritionally demanding period (Nana and Zema, 2018) as well as an appropriate time to adjust dietary habits and successfully introduce recommended nutrition-related lifestyle changes because many pregnant women are concerned about the health of their unborn child (Meija and Rezeberga, 2017).

In 2018 , seven percent of women of childbearing age and 32 percent of children under five suffered from malnutrition (United Nations Children's Fund, 2018). Poor maternal and childbirth outcomes have continued to be recorded as part of the most serious health and development challenges facing $\mathrm{Ni}$ geria in both rural and urban areas (Abbott, 2014). Appropriate nutrition in pregnancy essentially entails the consumption of adequate amount of protein from sources such as fish, dairy products that have low fat content, lean meat, farm meat and plant proteins to enhance the healthy development of maternal and fetal tissues (Meija and Rezeberga, 2017). Also, consumption of carbohydrate from wholegrain products and potatoes to provide energy and the exclusion or limiting of sweetened soft drink consumption to $25 \mathrm{~g}$ (five teaspoonfuls) to reduce the risk of obesity and; consumption of fats which contain omega 3 fatty acid from egg, snail and avocado is highly rec-

\footnotetext{
* Corresponding author: Phoebe Nwamaka Kanikwu, Edo University Iyamho, Department of Nursing Science, Iyamho, Edo State, Nigeria; e-mail: nwakanikwu@gmail.com http://doi.org/10.32725/kont.2021.004

Submitted: 2020-10-20 • Accepted: 2021-02-02 • Prepublished online: 2021-02-09 
ommended for fetal brain development (Zerfu and Biadgilign, 2018). Moreover, saturated fats contained in palm oil, butter and fatty meat should be restricted, and trans-fatty acids commonly used in producing dairy and confectionery products should be avoided because they contain partially hydrogenated vegetable fats (Meija and Rezeberga, 2017). Marangoni et al. (2016) also mentioned that fibre and fibre-rich products which contain minerals, vitamins and other biologically active substances are also recommended to prevent constipation, and to reduce the risk of haemorrhoidal vein disease, gestational diabetes and pre-eclampsia. The major sources of fibre include wholegrain products such as wholegrain bread, porridge, pasta as well as vegetables, legumes, dried and fresh fruit, nuts and seeds (Meija and Rezeberga, 2017). Again, a daily intake of at least $6-8$ glasses (4 litres) of water is recommended in pregnancy to aid the absorption of nutrients, preservation of amniotic fluid level and prevention of both dehydration and constipation (Marangoni et al., 2016; Meija and Rezeberga, 2017). Furthermore, folic acid is recommended for maternal erythropoiesis, DNA synthesis, growth of the placenta and the development of the fetal spinal cord within the first 4 weeks, while iron, calcium, iodine, and vitamins are also recommended for feto-maternal development (Marangoni et al., 2016).

Meeting the nutritional demand of pregnancy is crucial, hence nutrition education was included in the antenatal health education package (Kominiarek and Rajan, 2016). Nutrition education improves nutritional knowledge, thereby influencing perception, attitude and practices towards good nutrition (Girard and Olude, 2012). Pregnant womens' knowledge of nutrition is very important in creating good pregnancy outcomes and is crucial for improving children's nutritional status (Popa et al., 2013). Considering how knowledge of nutrition in pregnancy can affect a pregnant woman's decision to consume or avoid any food, and how the choice of food consumed throughout pregnancy can impact the outcome of the pregnancy, this study aims to assess nutrition in pregnancy and the outcome of the pregnancy among postpartum mothers in two Primary Health Centres in Okpanam, Delta State. Specifically, knowledge of nutrition in pregnancy, nutritional practices in pregnancy and the outcome of the pregnancy for the mother and child among postpartum mothers were assessed as a helpful approach to upgrade the current approach to counseling on diet in pregnancy.

\section{Materials and methods}

\section{Study design}

This study was a descriptive survey research.

\section{Location of the study}

The study took place in two Primary Health Centres in Okpanam Community, namely: Comprehensive Health Centre, Okpanam, and Primary Health Centre, Okpanam, Delta State. The Primary Health Centres were purposively selected because they are located in a densely populated rural area. The community is located in Oshimili North Local Government Area of Delta State in the south-south geopolitical zone of Nigeria and the people speak the enu-ani language. The community is bordered by Akwukwu Igbo, Atuma and the River Niger to the north, Asaba and Ugbolu to the east, Issele Azagba and Azagba Ogwashi to the west and, Ibusa to the South. The Okpanam community has two primary health centres, and a host of other private hospitals as the major providers of maternity care.

\section{Population of the study}

The population of the study comprised postpartum mothers whose delivery had taken place within the past 24 hours at the Comprehensive Health Centre, Okpanam and Primary Health Centre, Okpanam, Delta State. This category of postpartum mothers was selected because their pregnancy recently ended, so they could easily recall their nutritional practices and the outcome(s) of their pregnancy was still fresh in their memory. Mothers who were at least 18 years old, gave birth to single babies and resided in Okpanam community were included in the study. Convenience sampling was used to select 54 postpartum mothers who met the inclusion criteria.

\section{Data collection}

Data was collected using a researcher developed questionnaire which contains a total of twenty-eight (28) items and comprises four (4) sections (Sections A, B, C and D). Section A elicited information on the socio-demographic characteristics of the respondents, section $B$ elicited information on the knowledge of nutrition in pregnancy, section $C$ elicited information on nutritional practices in pregnancy and section $\mathrm{D}$ elicited information on the outcome of pregnancy for the mother and child. Two (2) research experts, lecturers in Maternal and Child Health Nursing from Madonna University, Elele, and the Measurement and Evaluation unit from Nnamdi Azikiwe University, Awka validated the instrument. The reliability of the instrument was established among five (5) respondents through pretest-posttest method at two (2) weeks interval in Comprehensive Health Centre, Illah, Delta State. The Cronbach alpha coefficient obtained was 0.845 . Copies of the questionnaire were administered face to face by the researchers and two (2) registered nurse-midwives in the facilities. The research assistants were instructed on how to assist the researchers in the administration, interpretation and retrieval of the questionnaire. Data collection was done within the first day postpartum after the woman had recovered from the exhaustion of labour and before discharge. The completed copies of the questionnaire were retrieved on the spot and there was $100 \%$ return rate. The data collection lasted for a period of eleven (11) weeks.

\section{Ethical consideration}

Written ethical clearance was obtained from the Primary Health Care Development Authority, Akwukwu Igbo, Delta State. The Medical Doctors and Matrons in charge of the two Primary Health Centres in Okpanam community were informed with a supporting formal letter and permission was gained. Participation in this study was voluntary and the identification information of participants was not recorded anywhere on the questionnaire.

\section{Data analysis}

Data analysis was done from a descriptive perspective using Statistical Package for Social Sciences (SPSS) version 22. The analyzed data were reported in the form of frequency, percentages and pie chart. Sections $B$ and $C$ were assessed with a dichotomous response of 'yes' or 'no'. A score of 1 or 0 was given to correct and wrong answers respectively. A cut-off of $50 \%$ was designated as acceptable. Knowledge and practice levels were categorized as poor level for score $<25 \%$ and low level for score of $26 \%$ to $50 \%$. A score of $51 \%$ to $74 \%$ was regarded as good level of knowledge and practice, while $>75 \%$ was regarded as very good level of knowledge and practice. 


\section{Results}

Table 1 shows that a majority of the respondents (30 respondents $-55.6 \%$ ) were within the age bracket of $27-35$ years, while a minority of 5 (9.3\%) were aged $36-44$ years. 36 (66.7\%) of the pregnant women had at least secondary level of education, while 18 (33.3\%) had primary level of education. The occupation of 33 (61.1\%) respondents was business/trading, while $2(3.7 \%)$ were unemployed. Among the respondents, $49(90.8 \%)$ were multiparous, while 5 (9.3\%) were primiparous; 45 (83.3\%) of the pregnant women delivered at full term.

Table 1. Respondents' socio-demographic characteristics $(n=54)$

\begin{tabular}{|c|c|c|c|c|}
\hline $\mathrm{S} / \mathrm{N}$ & Variables & Variable classification & Frequency & Percentage (\%) \\
\hline & \multirow{3}{*}{ Age (in years) } & $18-26$ & 19 & 35.2 \\
\hline & & $27-35$ & 30 & 55.6 \\
\hline & & $36-44$ & 5 & 9.3 \\
\hline & \multirow{3}{*}{ Highest level of education } & Primary & 18 & 33.3 \\
\hline & & Secondary & 21 & 38.9 \\
\hline & & Tertiary & 15 & 27.8 \\
\hline & \multirow{4}{*}{ Occupation } & None & 2 & 3.7 \\
\hline & & Farming & 9 & 16.7 \\
\hline & & Business/Trading & 33 & 61.1 \\
\hline & & Employed & 10 & 18.5 \\
\hline & \multirow{4}{*}{ Number of deliveries } & None & 5 & 9.3 \\
\hline & & 1 & 18 & 33.3 \\
\hline & & $2-4$ & 28 & 51.9 \\
\hline & & 5 and above & 3 & 5.6 \\
\hline & \multirow{4}{*}{ Gestational age at delivery (in weeks) } & 37-38 weeks (early term) & 2 & 3.7 \\
\hline & & 39-40 weeks (full term) & 45 & 83.3 \\
\hline & & 41 (late term) & 5 & 9.3 \\
\hline & & 42 weeks (post term) & 2 & 3.7 \\
\hline
\end{tabular}

Table 2. Knowledge of nutrition in pregnancy among respondents $(n=54)$

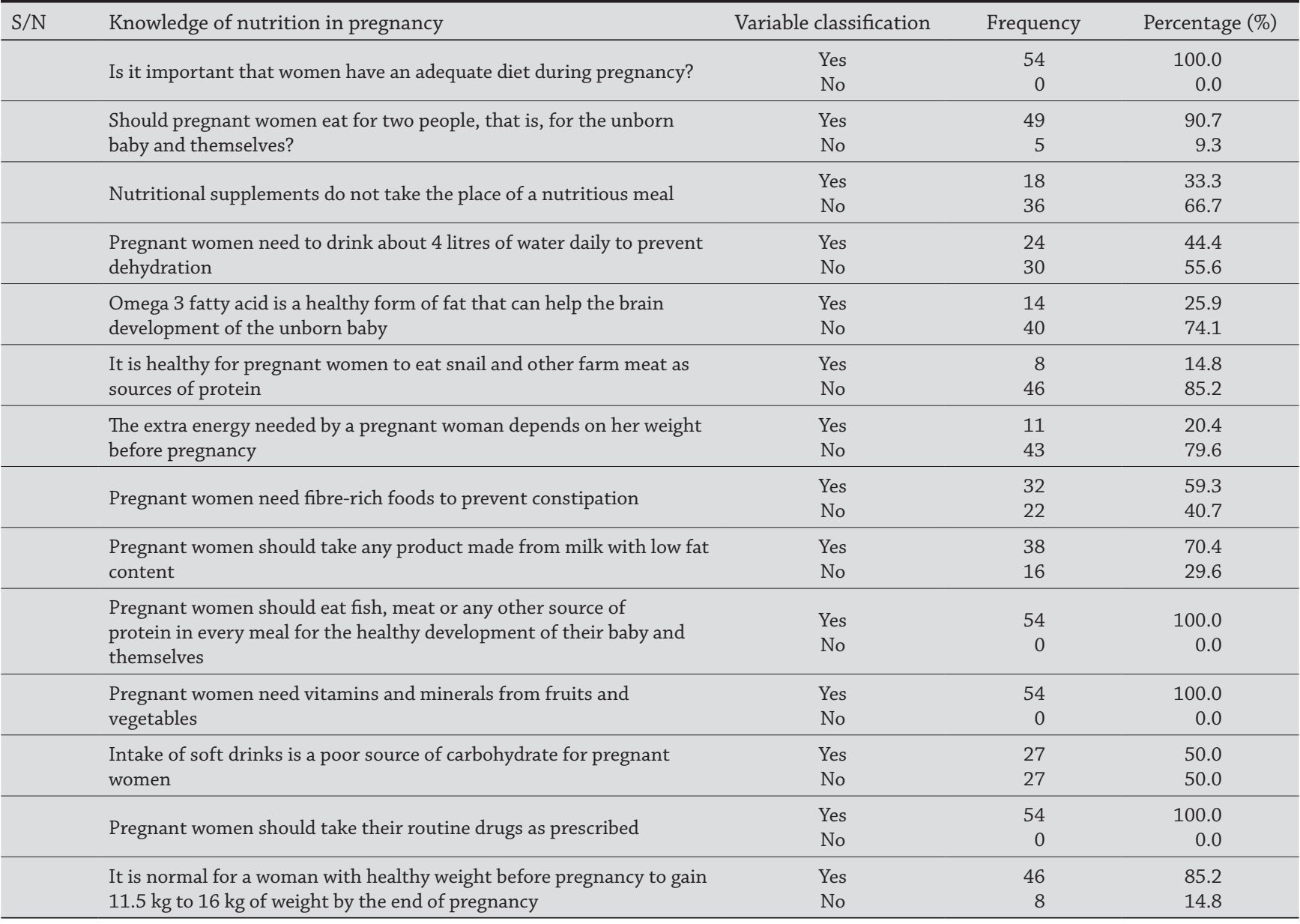


Table 2 shows that all the respondents knew that it was important for women to have an adequate diet during pregnancy but only $9.3 \%$ knew that this did not mean pregnant women should eat for two people. Less than half of the pregnant women $(33.3 \%)$ knew that nutritional supplements do not take the place of a nutritious meal. $44.4 \%$ knew that pregnant women need to drink about 4 litres of water daily to prevent dehydration. A few of the respondents knew that omega 3 fatty acid is a healthy form of fat that helps the brain development of the unborn baby (25.9\%), that it is healthy for pregnant women to eat snails and other farm meats as sources of protein (14.8\%), and that the extra energy needed by a pregnant woman depends on her weight before pregnancy (20.4\%). Among the respondents, $59.3 \%$ knew that pregnant women need fibre-rich foods to prevent constipation, $70.4 \%$ knew that pregnant women should take any product made from milk with low fat content, and $85.2 \%$ knew that it was normal for a woman with healthy weight before pregnancy to gain $11.5 \mathrm{~kg}$ to $16 \mathrm{~kg}$ of weight by the end of pregnancy. All the pregnant women knew that every meal should contain fish, meat or any other source of protein for the healthy development of their baby and themselves, that vitamins and minerals from fruits and vegetables were needed in pregnancy, and that pregnant women should take their routine drugs as prescribed. However, only $50 \%$ knew that soft drinks were a poor source of carbohydrate for pregnant women.

Fig. 1 shows that less than half (35.7\%) of the respondents had very good level of knowledge, only a few (14.3\%) had good level of knowledge, (28.6\%) had low level of knowledge and about one-fifth (21.4\%) had poor level of knowledge. An overall $50 \%$ level of knowledge indicated a low level of knowledge for nutrition in pregnancy among the postpartum mothers' in Comprehensive and Primary Health Centres, Okpanam, Delta State.

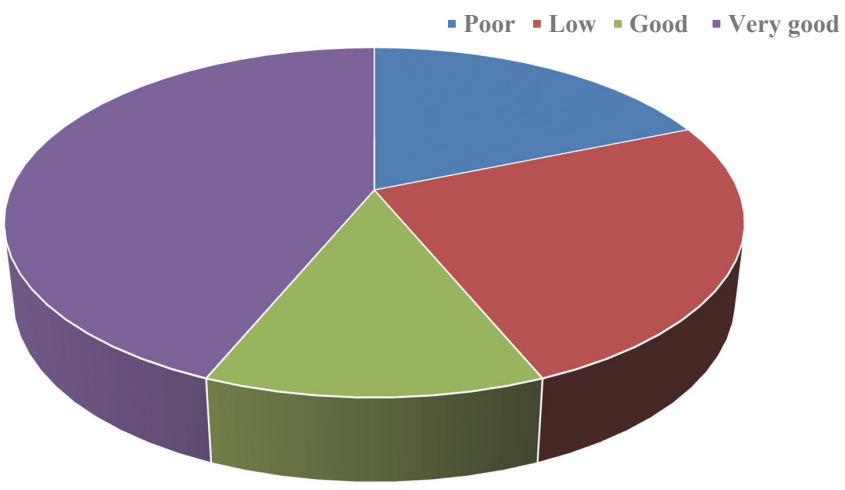

Fig. 1. Overall level of knowledge on nutrition in pregnancy

Table 3 shows that the majority of the respondents (79.6\%) did not reduce consumption of fried food during pregnancy, $75.9 \%$ did not drink up to 4 litres of water in pregnancy, $83.3 \%$ ate more fruits and vegetables in pregnancy, $63 \%$ reduced their consumption of sweet beverages in pregnancy, and $64.8 \%$ did not consume fewer soft drinks in pregnancy compared to before pregnancy. All the respondents said that they included meat, fish, beans or bean products in every meal during pregnancy, while $50 \%$ consumed less confectionary products in pregnancy.

Fig. 2 shows that $28.6 \%$ of the respondents had very good level of practice, $14.3 \%$ had good level of practice, $28.6 \%$ had low level of practice, and $28.6 \%$ had poor level of practice. An overall $42.9 \%$ level of practice indicated a low level of nutritional practice in pregnancy among the postpartum mothers' in Comprehensive and Primary Health Centres, Okpanam, Delta State.

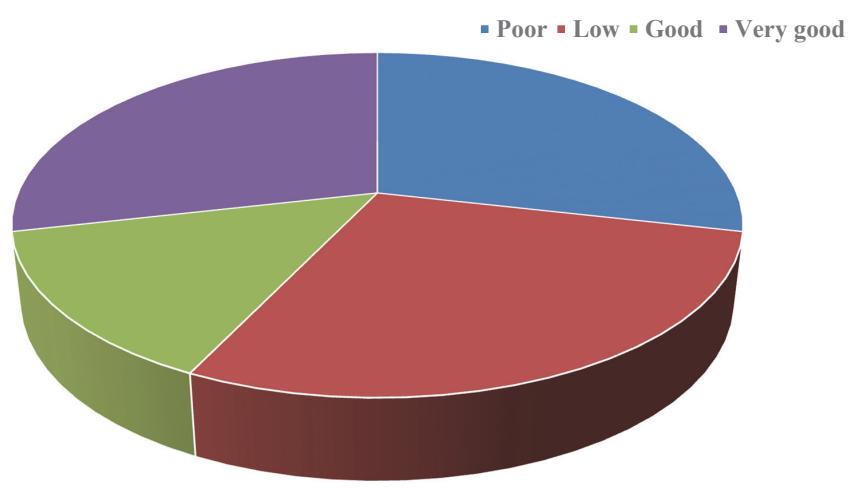

Fig. 2. Overall level of nutritional practice in pregnancy

Table 4 shows that $66.7 \%$ of the respondents said they had normal delivery, but others reported perineal tear (27.8\%), and postpartum haemorrhage (5.6\%). The indication of this finding is that $66.7 \%$ of the postpartum mothers in Comprehensive and Primary Health Centres, Okpanam, Delta State had good pregnancy outcome.

Table 4 also shows that $50 \%$ of the babies possessed normal features at birth, $7.4 \%$ had cleft lip/palate, while some others suffered asphyxia (9.3\%), were small for gestational age (14.8\%), were large for gestational age $(11.1 \%)$, and $7.4 \%$ had pathological jaundice. The result implied that only half (50\%) of the babies delivered by the postpartum mothers in Comprehensive and Primary Health Centres, Okpanam, Delta State had good pregnancy outcome.

\section{Discussion}

This study provides new data on nutrition in pregnancy and pregnancy outcome among postpartum mothers in two primary health care facilities. The findings of this study revealed that postpartum mothers had low level of knowledge regarding nutrition in pregnancy. This finding was supported by the findings of Fouda et al. (2012), which showed that about half of the childbearing age women in Egypt did not have enough knowledge on the meaning, importance and constituents of adequate diet in pregnancy. The similarity between these findings may be because most of the respondents were multiparous women who often admit that prenatal health education sessions including those on nutrition should be reserved for primigravid women. In another study conducted by Kever et al. (2015) in Borno State and Mugyia et al. (2016) in Yaounde, it was observed that knowledge of pregnant women was good and satisfactory, respectively. The results of this study showed that all the respondents knew that an adequate diet during pregnancy was very important, but only a few knew that this did not necessarily mean "eat for two". Similarly, Ugwa (2016) found out that all the pregnant women attending antenatal care at General Hospital, Kano believed that women should eat more during pregnancy to have healthy babies. According to Danielewicz et al. (2017), as long as the woman had a healthy weight before pregnancy, no additional calories are 
Table 3. Postpartum mothers' nutritional practices in pregnancy $(n=54)$

\begin{tabular}{|c|c|c|c|c|}
\hline $\mathrm{S} / \mathrm{N}$ & Nutritional practices in pregnancy & Variable classification & Frequency & Percentage (\%) \\
\hline & \multirow{2}{*}{$\begin{array}{l}\text { Reduced consumption of fried food in pregnancy compared to before } \\
\text { pregnancy }\end{array}$} & Yes & 11 & 20.4 \\
\hline & & No & 43 & 79.6 \\
\hline & \multirow{2}{*}{ Drank up to 4 litres of water in pregnancy } & Yes & 13 & 24.1 \\
\hline & & No & 41 & 75.9 \\
\hline & \multirow{2}{*}{$\begin{array}{l}\text { Ate more fruits and vegetables in pregnancy compared to before } \\
\text { pregnancy }\end{array}$} & Yes & 45 & 83.3 \\
\hline & & No & 9 & 16.7 \\
\hline & \multirow{2}{*}{ Reduced consumption of sweet beverages in pregnancy } & Yes & 34 & 63.0 \\
\hline & & No & 20 & 37.0 \\
\hline & \multirow{2}{*}{$\begin{array}{l}\text { Consumed fewer soft drinks in pregnancy compared to before } \\
\text { pregnancy }\end{array}$} & Yes & 19 & 35.2 \\
\hline & & No & 35 & 64.8 \\
\hline & \multirow{2}{*}{$\begin{array}{l}\text { Included meat, fish, beans or bean product in every meal during } \\
\text { pregnancy }\end{array}$} & Yes & 54 & 100.0 \\
\hline & & No & 0 & 0.0 \\
\hline & \multirow{2}{*}{$\begin{array}{l}\text { Consumed less confectionary products in pregnancy compared to } \\
\text { before pregnancy }\end{array}$} & Yes & 27 & 50.0 \\
\hline & & No & 27 & 50.0 \\
\hline
\end{tabular}

Table 4. Outcome of the pregnancy for mother and child among respondents $(n=54)$

\begin{tabular}{lrr}
\hline S/N & Futcome of the pregnancy & Percentage (\%) \\
\hline Outcome of the pregnancy for the mother & 36 & 66.7 \\
\hline Normal & 15 & 27.8 \\
\hline Perineal tear & 3 & 5.6 \\
\hline Postpartum haemorrhage & & 50.0 \\
\hline Outcome of the Pregnancy for the child & 27 & 7.4 \\
\hline Normal & 4 & 9.3 \\
\hline Birth defect & 5 & 14.8 \\
\hline Asphyxia & 8 & 11.1 \\
\hline Small for gestational age (birthweight $<2.5 \mathrm{~kg})$ & 6 & 7.4 \\
\hline Large for gestational age (birthweight $>3.5 \mathrm{~kg})$ & 4 & 7 \\
\hline Jaundice & & \\
\hline
\end{tabular}

needed in the first trimester even in multiple gestation, but about $266-360 \mathrm{kcal} /$ day is needed in the second trimester, and about 437-496 kcal/day is needed in the third trimester. In the opinion of Durgra (2012), many women eat to satisfy cravings in pregnancy.

Furthermore, only a few respondents knew that nutritional supplements do not take the place of a nutritious meal (33.3\%), omega 3 fatty acid is a healthy form of fat that helps the brain development of the unborn baby (25.9\%), it is healthy for pregnant women to eat snail and other farm meat as sources of protein (14.8\%) and, that the extra energy needed by a pregnant woman depends on her weight before pregnancy (20.4\%). This is opposed to the findings of Lim et al. (2018), which revealed that the majority (86.4\%) of the participants in their study in Malaysia knew that the extra energy needed in pregnancy was based on the woman's BMI before pregnancy, and that both omega- 3 and omega- 6 fatty acids were essential for brain and retina development of the fetus. Also, in a similar study in Lagos State, Fasola et al. (2018) affirmed that avoiding certain kinds of meat and fish was common in pregnancy because of taboos relating to their consumption. In the researchers opinion, taboos greatly influence pregnant women's knowledge regarding diet in pregnancy. The observation that all the respondents knew that pregnant women should take their routine drugs as prescribed, need fibre-rich foods (59.3\%), milk with low fat content $(70.4 \%)$, fruits and vegetables (100\%), and need fish, meat or any other source of protein in every meal (100\%) are related to the findings of Fasola et al. (2018) who reported that $95.08 \%$ of participants in their study in Lagos State knew that a pregnant woman should increase fruits and vegetables intake. A study by Mohammed and Helegbe (2020) revealed that pregnant women in Ghana adhered to folic acid (63\%), ferrous sulphate (63\%) and multivitamins (58\%). Lim et al. (2018) also found that $67 \%$ of pregnant women in Malaysia knew that the daily recommended intake of protein during pregnancy is $25 \mathrm{~g}$. Also, valuable information was gathered from questions that revealed $85.2 \%$ of the respondents knew it was normal for a woman with healthy weight before pregnancy to gain $11.5 \mathrm{~kg}$ to $16 \mathrm{~kg}$ of weight by the end of pregnancy, that intake of soft drink was a poor source of carbohydrate for pregnant women (50\%), and that pregnant women need to drink about 4 litres of water daily to prevent dehydration (44.4\%). The observation that $55 \%$ of pregnant women in Malaysia knew that if a woman had normal weight before pregnancy, she should gain between $11.5 \mathrm{~kg}$ and $16.0 \mathrm{~kg}$ during pregnancy supports the researchers' findings (Lim et al., 2018). Findings of this study on the need to drink about 4 litres of water daily in pregnancy and knowing 
that intake of soft drink was a poor source of carbohydrate for pregnant women could not be compared, because no previous study known to the researchers described similar result.

Another important finding was that postpartum mothers had a low level (42.9\%) of nutritional practice in pregnancy. A study by Daba et al. (2013) showed that there was a low level (33.9\%) of nutritional practice among pregnant in Ethiopia. In the authors' opinion, having a low level of nutritional practice may directly reflect their level of knowledge. The results of this study showed that the majority (79.6\%) of the respondents consumed much fried food, less than 4 litres of water daily (75.9\%), more fruits/vegetables (83.3\%), reduced consumption of sweet beverages (63\%) and, increased consumption of soft drinks in pregnancy compared to before pregnancy (64.8\%). Similarly, $80 \%$ of childbearing age women in Lagos State increased their daily consumption of fruits and vegetables, $90 \%$ consumed more fast food, and $43.6 \%$ avoided chocolate beverages because it was a food taboo in pregnancy (Fasola et al., 2018). Also, $86 \%$ agreed that they had adequate intake of oil, fruits and vegetables (56\%) during pregnancy (Ugwa, 2016). Zhou et al. (2019) discovered that on average, the total water intake of pregnant women in China was $2638 \mathrm{ml} /$ day. All the respondents in this study said that they included meat, fish, beans or bean product in every meal, and $50 \%$ consumed less confectionary products during pregnancy. Contradicting this finding, $43.6 \%$ of childbearing age women in Lagos State avoided eggs, fish and meat during pregnancy (Fasola et al., 2018).

The findings of this study revealed that more than half (66.7\%) of postpartum mothers had good pregnancy outcome. In a similar study by Gudayu and Araya (2019), it was reported that nearly three quarters $(70 \%)$ of postnatal mothers in Debre Tabor experienced good birth outcome and were discharged without having complications. In the present study, the results showed that $27.8 \%$ suffered perineal tear, and $5.6 \%$ suffered postpartum haemorrhage. The common complications recorded among postnatal mothers in Debre Tabor were postpartum haemorrhage (11\%) and perineal tear $(5.7 \%)$ (Gudayu and Araya, 2019). Malnutrition has been recognized as one of the underlying factors for maternal death and poor maternal outcome of pregnancy (Gudayu and Araya, 2019). The causes of malnutrition are multifactorial and multidimensional with poverty, maternal illiteracy and food inadequacy being the major culprits of this menace in developing countries which include Nigeria (Kever et al., 2015). In the authors' opinion, inappropriate dietary intake that results in large size babies could predispose pregnant women to perineal trauma during vaginal delivery. Likewise, antepartum anemia which could result from poor iron and vitamin intake, increases the risk of postpartum haemorrhage.

One more finding of this study was that $50 \%$ of the babies delivered by the postpartum mothers were normal, $7.4 \%$ had cleft lip/palate, asphyxia (9.3\%), small for gestational age (14.8\%), large for gestational age $(11.1 \%)$, and $7.4 \%$ had pathological jaundice. In an epidemiological review by Abu-Saad and
Fraser (2010) and a study by Rayco-Solon et al. (2005) it was found that in rural India, small-for-gestational age birth was highest at the end of the "hungry" season and was negatively associated with maternal weight gain. Also, higher maternal food intake coupled with lower levels of strenuous activity in late gestation was found to be associated with increased birth size in rural India (Rao et al., 2009). Although the scope of the present study did not show any link between maternal nutrition and activity with birth outcomes, the authors feel that further studies are needed in this area to identify the relationship.

\section{Conclusions}

Postpartum mothers in Comprehensive and Primary Health Centres, Okpanam, Delta State had low knowledge level of nutrition in pregnancy and low level of nutritional practice in pregnancy. Also, the majority of the postpartum mothers had good maternal pregnancy outcome and about half of them delivered babies with good pregnancy outcome. These findings are helpful information to modify the current approach to the health education of pregnant women on nutrition/diet, in order to prevent malnutrition in pregnancy. Furthermore, the findings of this study contribute to the existing body of knowledge on the assessment of nutrition in pregnancy and pregnancy outcomes related to maternal prenatal nutrition, thus serving as reference for subsequent related studies in Nigeria and other parts of the world. It is recommended that more health education about prenatal nutritional needs, prenatal nutrition and its effect on the outcome of pregnancy should be conducted to correct misconceptions, improve knowledge and upgrade the current health education guidelines with new findings. Also, awareness of the nutritional benefits of indigenous foods should be intensified, and farmers/agriculturists should be encouraged to increase the cultivation and availability of indigenous foods with nutritional benefits in pregnancy.

\section{Funding}

The authors funded the entire research work.

\section{Acknowledgements}

The authors wish to thank the study participants, research assistants and staff of Comprehensive Health Centre, Okpanam and Primary Health Centre, Okpanam.

\section{Contributions}

PNK designed study instrument, drafted original manuscript, analyzed data. PNK, JAJ, and ACE participated in conception, data collection, interpretation of data and revising of manuscript.

\section{Conflict of interests}

The authors have no conflict of interests to declare. 


\section{Výživa v těhotenství a výsledek těhotenství ve dvou primárních zdravotních střediscích v Okpanamu}

\section{Souhrn}

Úvod: Těhotenství je z hlediska výživy rizikovým obdobím. Feto-mateřské výsledky těhotenství lze odvodit z nutričního stavu matky před porodem.

Cíl: Studie hodnotila znalosti matek po porodu ohledně výživy v těhotenství, nutričních postupů v těhotenství a výsledek těhotenství pro matku a dítě.

Metody: Popisný dotazníkový výzkum 54 matek po porodu, které navštěvovaly dvě primární zdravotní centra v Okpanamu ve státě Delta. Data shromážděná pomocí vlastního dotazníku byla analyzována pomocí Statistického balíčku pro sociální vědy (SPSS) verze 22 a popsána z hlediska četnosti, procent a ve formě koláčového grafu.

Výsledky: 90,7 \% uvedlo, že těhotné ženy by měly jíst za dvě osoby, tedy za sebe a nenarozené dítě, a 35,2 \% konzumovalo během těhotenství méně slazených nealkoholických nápojů. Úroveň znalostí 50 \% matek a úroveň nutriční praxe 42,9 \% matek ukázala na nízkou úroveň znalostí o výživě v těhotenství i nízkou úroveň výživy v těhotenství; 66,7 \% matek po porodu mělo dobrý výsledek těhotenství a asi 50 \% jejich dětí mělo dobré poporodní výsledky.

Závěr: Ženy po porodu měly nízkou úroveň znalostí o výživě a nízkou úroveň výživy v těhotenství. Většina měla dobrý výsledek těhotenství, ale jen asi polovina jejich dětí měla dobré poporodní výsledky.

Klíčová slova: nutriční praxe; těhotenství; výsledek těhotenství; výživa; znalosti

\section{References}

1. Abbott L (2014). The pregnant woman in prison. Howard League for Penal Reform ECAN bulletin, 23.

2. Abu-Saad K, Fraser D (2010). Maternal nutrition and birth outcomes. Epidemiological Review 32(1): 5-25. DOI: 10.1093/ epirev/mxq001.

3. Daba G, Beyene F, Fekadu H, Garoma W (2013). Assessment of knowledge of pregnant mothers on maternal nutrition and associated factors in Guto Gida Woreda, East Wollega Zone, Ethiopia. Journal of Nutritional Disorders and Therapy 4(1): 130. DOI: $10.4172 / 2161-0509.1000130$.

4. Danielewicz H, Myszczyszyn G, Debinska A, Myszkal A, Boznanski A, Hirnle L (2017). Diet in pregnancy - more than food. Eur J Peadiatr 176(12): 1573-1579. DOI: 10.1007/ s00431-017-3026-5.

5. Durgra $P$ (2012). Dietary reference intake. Dietary Journal of Amdra Tribe 3(2): 10-15.

6. Fasola O, Abosede O, Fasola FA (2018). Knowledge, attitude and practice of good nutrition among women of childbearing age in Somolu Local Government, Lagos State. J Public Health Afr 9(1): 793. DOI: 10.4081/jphia.2018.793.

7. Fouda LM, Ahmed MH, Shehab NS (2012). Nutritional awareness of women during pregnancy. J Am Sci 8(7): 494-502.

8. Girard AW, Olude O (2012). Nutrition education and counselling provided during pregnancy: Effects on maternal, neonatal and child health outcomes. Paediatr Perinat Epidemiol 26(Suppl. 1): 191-204. DOI: 10.1111/j.13653016.2012.01278.x.

9. Gudayu TW, Araya BM (2019). Outcomes among mothers who gave birth in the health facility: Does birth preparedness and complication readiness have a role? Obstetrics and Gynecology International 2019: 47-53. DOI: 10.1155/2019/5147853.

10. Kever RT, Martins SD, Lola N, Dathini H, Habu H, Fatima AA, Sambo BD (2015). Knowledge and attitude of pregnant women towards dietary practices in Yerwa Clinic, Maiduguri Metropolitan Council; Borno State. Journal of Research in Nursing and Midwifery 4(1): 12-19. DOI: 10.14303/ JRNM.2014.027.

11. Kominiarek M, Rajan P (2016). Nutrition Recommendations in Pregnancy and Lactation. Med Clin North Am 100(6): 11991215. DOI: 10.1016/j.mcna.2016.06.004.

12. Lim ZX, Wong JL, Lim PY, Soon LK (2018). Knowledge of nutrition during pregnancy and associated factors among antenatal mothers. Int J Public Health Clinic Sci 5(1): 117-128.
13. Marangoni F, Cetin I, Veruci E, Canzone G, Giovannini M, Scollo P, et al. (2016). Maternal Diet and Nutrient Requirements in Pregnancy and Breastfeeding. An Italian Consensus Document. Nutrients 8(10): 629. DOI: 10.3390/nu8100629.

14. Meija L, Rezeberga D (2017). Proper maternal nutrition during pregnancy planning and pregnancy: A healthy start in life. [online] [cit. 2020-01-22]. Available from: https://www. euro.who.int/en/health-topics/disease-prevention/nutrition/ publications/2017/proper-maternal-nutrition-duringpregnancy-planning-and-pregnancy-a-healthy-start-in-life-2017

15. Mohammed BS, Helegbe GK (2020). Routine haematinics and multivitamins: Adherence and its association with haemoglobin level among pregnant women in urban lower-middle-income country, Ghana. Basic Clin Pharmacol Toxicol 127(1): 21-29. DOI: $10.1111 /$ bcpt.13390.

16. Mugyia ASN, Tanya AKN, Njotang PN, Ndombo PK (2016). Knowledge and attitudes of pregnant mothers towards maternal dietary practices during pregnancy at the Etoug-Ebe Baptist Hospital Yaounde. J Med Health Sci 17(2).

17. Nana A, Zema T (2018). Dietary practices and associated factors during pregnancy in northwestern Ethiopia. BMC Pregnancy Childbirth 18: 183.

18. Popa AD, Niţä O, Arhire LIG, Popescu RM, Botnariu GE, Mihalache L, Graur M (2013). Nutritional knowledge as a determinant of vitamin and mineral supplementation during pregnancy. BMC Public Health 13(1): 1105. DOI: 10.1186/14712458-13-1105.

19. Rao S, Kanade AN, Yajnik CS, Fall CHD (2009). Seasonality in maternal intake and activity influence offspring's birth size among rural Indian mothers-pune maternal nutrition study. Int J Epidemiol 38(4): 1094-1103. DOI: 10.1093/ije/dyp223.

20. Rayco-Solon P, Fulford AJ, Prentice AM (2005). Differential effects of seasonality on preterm birth and intrauterine growth restriction in rural Africans. Am J Clin Nutr 81(1): 134-139. DOI: 10.1093/ajcn/81.1.134.

21. Ugwa EA (2016). Nutritional practices and taboos among pregnant women attending antenatal care at General Hospital in Kano, Northwest Nigeria. Ann Med Health Sci Res 6(2): 109-114. DOI: 10.4103/2141-9248.181846.

22. United Nations Children's Fund (2018). Nutrition. [online] [cit. 2019-02-02]. Available from: www.unicef.org/nigeria/nutrition

23. World Health Organization (2018). WHO recommendation on counselling on healthy eating and physical activity during pregnancy. [online] [cit. 2018-06-08]. Available from: https://extranet.who.int/rhl/topics/preconceptionpregnancy-childbirth-and-postpartum-care/antenatal-care/ who-recommendation-counselling-healthy-eating-and-physicalactivity-during-pregnancy 
24. Zerfu TA, Biadgilign S (2018). Pregnant mothers have limited knowledge and poor dietary diversity practices, but favorable attitude towards nutritional recommendations in rural

Ethiopia: evidence from community-based study. BMC Nutr 4: 43. DOI: $10.1186 / \mathrm{s} 40795-018-0251-x$.
25. Zhou Y, Zhu X, Qin Y, Li Y, Zhang M, Liu W, Huang H, Xu Y (2019). Association between total water intake and dietary intake of pregnant and breastfeeding women in China. BMC Pregnancy and Childbirth 19(172). 